LAWYERS, SWAMPS, AND MONEY 



\section{Lawyers, Swamps, and Money}

U.S. WETLAND LAW, POLICY, AND POLITICS

Royal C. Gardner

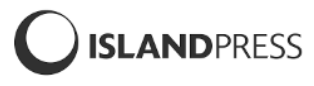

Washington | Covelo | London 


\section{Copyright (C) 2011 Royal C. Gardner}

All rights reserved under International and Pan-American Copyright Conventions. No part of this book may be reproduced in any form or by any means without permission in writing from the publisher: Island Press, 1718 Connecticut Ave., NW, Suite 300, Washington, DC 20009.

ISLAND PRESS is a trademark of the Center for Resource Economics.

Library of Congress Cataloging-in-Publication Data

Gardner, Royal C.

Lawyers, swamps, and money : U.S. wetland law, policy, and politics / Royal C. Gardner.

p. cm.

Includes bibliographical references and index.

ISBN-13: 978-1-59726-814-1 (cloth : alk. paper)

ISBN-10: 1-59726-814-3 (cloth : alk. paper)

ISBN-13: 978-1-59726-815-8 (pbk. : alk. paper)

ISBN-10: 1-59726-815-1 (pbk. : alk. paper) 1. Wetlands-Law and legislationUnited States. 2. Wetland conservation-Law and legislation-United States. 3. Wetland mitigation banking-United States. I. Title.

KF5624.G37 2011

$333.91^{\prime} 80973-\mathrm{dc} 22$

2010041634

Printed on recycled, acid-free paper

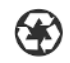

Manufactured in the United States of America $\begin{array}{lllllllllll}10 & 9 & 8 & 7 & 6 & 5 & 4 & 3 & 2 & 1\end{array}$

Keywords: administrative law; Clean Water Act; wetland mitigation banking; in-lieu fee mitigation; dredge and fill; regulatory takings; Army Corps of Engineers; Rapanos v. United States; no net loss; watershed 


For Mom and Dad with love 

Introduction 1

Chapter 1 The Ebb and Flow of Public Perceptions of Wetlands 5

Chapter 2 Administrative Law: The Short Course 15

What are agencies and who made them the boss? 17

What exactly does an agency do? 22

How are regulations made? 23

What's the difference between a regulation and mere guidance? 25

Navigating from statute to regulation to guidance 25

I'm mad as hell and not going to take it anymore:

How to challenge agency actions 28

Executive Branch $\quad 28$

Legislative Branch $\quad 29$

The Media $\quad 29$

Judicial Branch $\quad 30$

CONSTITUTIONAL CONSIDERATIONS $\quad 30$

STATUTORY STANDING 32

RIPENESS $\quad 33$

CHEVRON DEFERENCE 33

Chapter 3 What's a Wetland (for purposes of Clean Water Act jurisdiction)? 35

The initial interpretation of "waters of the United States":

We've always done it this way. $\quad 37$

United States v. Riverside Bayview Homes:

Unanimity on adjacent wetlands $\quad 39$

Solid Waste Agency of Northern Cook County v. U.S. Army

Corps of Engineers: A split decision on

"isolated" waters 
Rapanos v. United States: A trifurcation of confusion

Does dredging (and sidecasting) require a Clean Water Act permit?

Neatness counts: Exploiting a loophole

The inevitable blowback: The regulated community responds.

Deep plowing or deep ripping? The Borden Ranch case 64

Strange things done in the midnight sun: Gold mining waste as fill

Chapter 5 Strange Bedfellows: The U.S. Environmental Protection Agency and the U.S. Army Corps of Engineers

The misnamed 404(b)(1) Guidelines:

More than mere guidance

The heart of the Guidelines: The alternatives analysis

Fund for Animals v. Rice: The alternatives analysis in practice

Defining the project purpose of a golf course:

Mississippi casinos: Is gambling a water-dependent activity?

Sweedens Swamp and the market-entry theory:

"It depends on what the meaning of the word 'is' is." 84

The mitigation MOA: Resolving the buy-down and sequencing dispute

The old Corps returns: The EPA vetoes the Yazoo River Project

Chapter 6 No Net Loss: Lies, Damned Lies, and Statistics

The starting point: A nation of farmers 94

If you build it, they will come. 95

The other illegal alien problem: Invasive species 97

Agricultural sticks and carrots: Swampbuster and the Wetlands Reserve Program 
Offsetting development impacts: Compensatory mitigation 101

The Cajun solution: Eat a nutria, save a wetland. 102

Net gains on agricultural lands 104

Paper gains, real losses: The failure of permittee-responsible compensatory mitigation $\quad 105$

No net loss: Mission accomplished? 109

Chapter 7 Wetland Mitigation Banking: Banking on Entrepreneurs 111

What is wetland mitigation banking? 112

The legal status of mitigation banking (the early years) 114

Pembroke Pines: The first sale of credits from an entrepreneurial mitigation bank $\quad 115$

$\begin{array}{ll}\text { The } 1995 \text { mitigation banking guidance } & 117\end{array}$

Congress provides a market (and ratifies the guidance). 119

How much can I sell a wetland credit for? 120

The good, the bad, and the ugly 123

Panther Island Mitigation Bank (Florida) 123

Mud Slough (Oregon) 124

Black River Basin Mitigation Bank (South Carolina) 124

Woodbury Creek (New Jersey) 125

They're only in it for the money (and other criticisms of mitigation banking). 126

Chapter 8 In-lieu Fee Mitigation: Money for Nothing? 129

What is in-lieu fee mitigation? 129

The legal status of in-lieu fee mitigation (the early years) 132

"Educational" mitigation 133

Conflict of interest: Agency as regulator and competitor? 134

Timing in life is everything. $\quad 135$

But they're the good guys! 136

$\begin{array}{ll}\text { The } 2000 \text { in-lieu fee guidance } & 137\end{array}$

Tracking in-lieu fee performance (or the lack thereof) 138

Chapter 9 Leveling the Mitigation Playing Field 141

An initial attempt at standards for permittee-responsible mitigation: The Halloween guidance 141

You could have at least called . . $\quad 142$

Lack of public input: Perhaps ill-advised, but legal 143

Out of chaos comes order: The National Mitigation

Action Plan 144

Congress (re-)enters the fray. $\quad 145$ 
Proposed compensatory mitigation rule

O'Hare Airport and the return of CorLands 147

Reconsidering in-lieu fee mitigation 149

Finally, the final rule emerges. 151

Sequencing and avoidance 151

Equivalency in mitigation plans $\quad 152$

Nonequivalency in the timing of the use of mitigation credits 153

The mitigation hierarchy $\quad 155$

But is the compensatory mitigation regulation good for the environment? 156

Chapter 10 Wetland Enforcement: The Ultimate Discretionary Act 159

Who is the lead enforcement agency? 159

Every day is a new day: The continuing violation theory 161

Hobson's choice: No pre-enforcement review of administrative orders 163

After-the-fact permits: All is forgiven. 164

Administrative penalties: Adjudication by the agencies $\quad 165$

Civil penalties: Potentially real money, rarely invoked 166

Settlements, supplemental environmental programs, and other payments 168

Criminal penalties: Muddy jackboots? 169

The least sympathetic defendants 171

Citizen suits: Backing up the government 172

Enforcement of permit conditions: A gap in citizen suits $\quad 172$

Enforcement of third-party mitigation providers:

Does responsible mean liable? $\quad 173$

Chapter 11 Regulatory Takings in the Wetland Context 177

Preliminary hurdles: Ripeness 178

Choosing a forum: U.S. District Court or the U.S. Court of Federal Claims 180

The Penn Central factors $\quad 181$

Applying the Penn Central factors: The Florida Rock saga 181

Of rats, rabbits, and reasonable investment-backed expectations 183

Lucas v. South Carolina Coastal Council: No need to balance factors 184

The irrelevance of Lucas 186

Reasonable investment-backed expectations revisited $\quad 187$ 
Chapter 12 Concluding Thoughts and Recommendations 191

Epilogue: Where Are They Now? 199

Appendix 209

Clean Water Act (excerpts) 209

EPA Regulations 40 CFR Part 230 (excerpts) 211

Corps Regulations 33 CFR Parts 320-332 (excerpts) 214

Clean Water Act Guidance Document (excerpts) 220

Endnotes 223

Selected References and Further Reading 229

Index 245 

Writing a book can be like wading through a swamp. It is full of surprises and discoveries, and one should not do it alone. That has certainly been the case for me.

I have been fortunate to have had a host of outstanding research assistants and Biodiversity Fellows who have helped me over the years. I especially would like to thank Marcela Bonells, Stephanie Broad, Michael Dema, Leah Ellington, Joshua Holmes, Melody James, Kristine Jones, Christine Krohn, Ezequiel Lugo, Noelle Nasif, and Michelle Sabin for their able research and dedication. Stephanie, Michael, and Marcela were particularly instrumental in finishing up this project.

I very much appreciate the support provided by Stetson University College of Law. It is a great place to work in part because of my wonderful colleagues. Dean Darby Dickerson, Ellen Podgor (past Associate Dean of Faculty Development), and Jamie Fox (current Associate Dean of Faculty Development) have always offered welcome encouragement. And the Office of Faculty Support and Stetson's law librarians have no peer.

The University of Granada Faculty of Law kindly afforded me a refuge to write during my sabbatical. My family and I treasure our time there and our dear friends, especially Antonio Sánchez Aranda and Yolanda Quesada Morillas.

Many, many people have educated me about wetland science and policy, including truly dedicated state and federal agency employees. In particular, I have benefitted immensely from working with my colleagues on the National Research Council Committee on Mitigating Wetland Losses, my previous co-authors Kim Diana Connolly and Theresa Pulley Radwan, Melanie Riedinger-Whitmore of the University of South Florida (with whom I team-teach an interdisciplinary wetland seminar), and my friends on the U.S. National Ramsar Committee and the Ramsar Scientific and Technical Review Panel. Earl Stockdale was my early mentor, and Michael Davis and Palmer Hough have always been willing to discuss and debate wetland issues with me. 
Jessica Wilkinson and Michael Davis provided valuable comments on portions of drafts of this book, for which I am very appreciative.

I would also like to thank my editor, Emily Davis, and the staff of Island Press for their thoughtful guidance and advice. Any errors or omissions are of course my responsibility alone.

Finally, I would like to express my love and gratitude to my wife, Mary Fahy, and our children, Colin and Meggie. The book was a team effort. Meggie contributed mythological references, Colin suggested opening each chapter with a quotation, and Mary reviewed and provided insightful comments on innumerable drafts. I am most thankful for their love and support (and patience) during this journey. 